\title{
P277: Situation analysis of patient safety and infection control in health institutions in postconflict in DR Congo
}

\author{
EN Dunia ${ }^{1 *}$, AM Kady $^{2}$ \\ From 2nd International Conference on Prevention and Infection Control (ICPIC 2013) \\ Geneva, Switzerland. 25-28 June 2013
}

\section{Introduction}

The State of infections acquired during care procedures whose prevalence rate is estimated at about $15 \%$ in some benchmark institutions reflects the alarming situation of provision of care and patient safety in DR Congo.

\section{Objectives}

Conduct an inventory of patient safety in health facilities in the city Kinshasa.

\section{Methods}

Study conducted using survey and observation checklist covering the different aspects of patient safety: institutional, medical technical equipment, medical devices, blood products, drugs, biological graft, waste management medical needles and treatment materials.

\section{Results}

At the institutional level: the lack of standards and policies on patient safety except on injection safety; lack of policy on the fight against nosocomial infections; reporting system for adverse events.

Technically: Absence of risk management procedures, training non-existent on the quality and safety of patients in Kinshasa (90\% of staff) and $89 \%$ of patients do not know their rights and lack of association of patient safety care.

\section{Conclusion}

The implementation of a policy of promotion of hospital hygiene and the fight against adverse events associated with their care requires a partnership challenging multiple

${ }^{1}$ RIPAQS, Kisangani,The Democratic Republic of the Congo

Full list of author information is available at the end of the article states, civil society, communicators, the private sector and international institutions.

\section{Competing interests}

None declared.

\section{Author details}

${ }^{1}$ RIPAQS, Kisangani, The Democratic Republic of the Congo. ${ }^{2}$ RIPAQS,

Kinshasa, The Democratic Republic of the Congo.

Published: 20 June 2013

doi:10.1186/2047-2994-2-S1-P277

Cite this article as: Dunia and Kady: P277: Situation analysis of patient safety and infection control in health institutions in postconflict in DR Congo. Antimicrobial Resistance and Infection Control 2013 2(Suppl 1): P277.

Submit your next manuscript to BioMed Central and take full advantage of:

- Convenient online submission

- Thorough peer review

- No space constraints or color figure charges

- Immediate publication on acceptance

- Inclusion in PubMed, CAS, Scopus and Google Scholar

- Research which is freely available for redistribution
C Biomed Central

(c) 2013 Dunia and Kady; licensee BioMed Central Ltd. This is an Open Access article distributed under the terms of the Creative Commons Attribution License (http://creativecommons.org/licenses/by/2.0), which permits unrestricted use, distribution, and reproduction in any medium, provided the original work is properly cited. 